\title{
Tindak Pidana Pencemaran Nama Baik di Media Sosial Berdasarkan Peraturan Perundang-Perundangan
}

\author{
W. Erfandy Kurnia Rachman, Muh Syarief Simatupang, Yessy Kurniani, Rela Putri \\ Mahasiswa Magister Ilmu Hukum, Fakultas Hukum Universitas Airlangga \\ fundee_mail@yahoo.com
}

Submit: 20-06-2020; Review: 28-05-2020; Terbit: 28-06-2020

\begin{abstract}
In this modern era, the progress of information technology, electronic media and globalization occur almost in all areas of life. Technological advances, like the internet can be operated using electronic media such as computers. The technology also provides a significant influence in the understanding of crime especially on streams in criminology that focus on humanity, both on the birth and psychological. One of the crimes committed by misusing the benefit of electronic and computer technology is the defamation case through social media. Freedom of opinion in Indonesia can be seen in the Constitution of Republic Indonesia Year 1945 on Article 28 (1). There will still be limitation, so the freedom of opinion does not turn as defamation. This arrangement is presented in the Criminal Code (KUHP). There are also some legislation regulating criminal defamation. In addition, in Law Number 19 Year 2016 on Amendment to Law of the Republic of Indonesia Number 11 Year 2008 on Information and Electronic Transactions (UU ITE), Law Number 40 Year 1999 regarding Press (Act on Press), and Law Number 32 Year 2002 About Broadcasting (Broadcasting Act).
\end{abstract}

Keywords: Technology, Defamation, Media Social.

\begin{abstract}
Abstrak
Kemajuan teknologi yang ditandai dengan munculnya internet dapat dioperasikan dengan menggunakan media elektronik seperti komputer. Teknologi juga memberikan pengaruh yang signifikan dalam pemahaman mengenai kejahatan terutama terhadap aliran-aliran dalam kriminologi yang menitikberatkan pada faktor manusia, baik secara lahir maupun psikologis. Salah satu kejahatan yang dilakukan dengan meyalahgunakan kecanggihan teknologi elektronik dan komputer adalah kasus pencemaran nama baik melalui media sosial. Kebebasan berpendapat di Indonesia dapat dilihat dalam Undang-Undang Dasar Negara Kesatuan Republik Indonesia Tahun 1945 pada Pasal 28 (1). Namun, terdapat pula pembatasan agar tidak menjadi pencemaran nama baik. Pengaturan pembatasan tersebut terdapat pada Kitab Undang-undang Hukum Pidana (KUHP). Terdapat pula beberapa peraturan perundang-undangan yang mengatur tentang tindak pidana pencemaran nama baik.
\end{abstract}


Selain yang diatur secara lex generalis dalam KUHP, terdapat juga pengaturan secara lex specialis dalam undang-undang di luar KUHP yaitu dalam UU Nomor 19 Tahun 2016 tentang Perubahan Atas Undang-Undang Republik Indonesia Nomor 11 Tahun 2008 tentang Informasi dan Transaksi Elektronik (UU ITE), UU Nomor 40 Tahun 1999 tentang Pers (UU Pers), dan UU Nomor 32 Tahun 2002 Tentang Penyiaran (UU Penyiaran).

Kata Kunci: Teknologi, Tindak Pidana Pencemaran Nama Baik, Media Sosial.

\section{Pendahuluan}

Setelah Indonesia bebas dari penjajahan Belanda, Pemerintah mengeluarkan Undang-Undang Nomor 1 Tahun 1946 yang didasarkan pada Pasal II Aturan Peralihan UndangUndang Dasar, bahwa : "Segala badan negara dan peraturan yang ada masih langsung berlaku selama belum diadakan yang baru menurut UndangUndang Dasar ini”. Lebih lanjut Undang-Undang Nomor 1 Tahun 1946 Pasal 1 menyatakan keberlakuan Wetboek van Strafrecht voor Nederlands-Indie yang diterjemahkan menjadi Kitab Undang-Undang Hukum Pidana. Hal ini merupakan asas konkordansi, yakni memberlakukan hukum negara jajahan di negara yang dijajah. Oleh karena itu, konsep negara hukum yang kemudian diterapkan oleh UUD NKRI 1945.

Salah satunya ialah penerapan hukum pidana di Indonesia yang berlaku di Indonesia sekarang ini ialah hukum pidana yang telah dikodifikasi, yaitu sebagian terbesar dari aturan aturannya telah disusun dalam satu kitab undang-undang hukum pidana menurut suatu sistem yang tertentu. Ketentuan-ketentuan dalam Bab 1 s/d Bab VIII dari Buku Ke-1 (aturanaturan umum), juga berlaku bagi perbuatan-perbuatan yang oleh aturan - aturan dalam perundangan lain di ancam dengan pidana, kecuali kalau di tentukan lain oleh undang-undang. Istilah perbuatan pidana adalah perbuatan yang dilarang oleh suatu aturan hukum larangan mana disertai ancaman (sanksi) yang berupa pidana 
tertentu, bagi barangsiapa yang melanggar larangan tersebut.

Dapat juga dikatakan bahwa perbuatan pidana adalah perbuatan yang oleh suatu aturan hukum dilarang dan diancam pidana, asal saja dalam pada itu diingat bahwa larangan ditujukan kepada perbuatannya (yaitu suatu keadaan atau kejadian yang ditimbulkan oleh kelakuan orang), sedangkan ancaman pidananya ditujukan kepada orang yang menimbulkan kejadian itu (Moeljatno, 2009 : 59).

Di dalam KUHP diatur secara detail dan hal kecil yang oleh masyarakat dianggap remeh, dan undang-undang tersebut mengatur tidak hanya perbuatan pidana yang identik dengan seseorang yang melakukan kejahatan pembunuhan, penipuan, perampokan tapi seseorang yang menjelek-jelekan orang lain di ketahui oleh umum yang biasa disebut pencemaran nama baik, penyebabnya beragam seperti melecehkan dengan tulisan, memfitnah, mengadu secara memfitnah, menuduh secara memfitnah. Pencemaran nama baik merupakan perkosaan terhadap kehormatan seseorang.

Di masa modern ini, kemajuan teknologi informasi, media elektronika dan globalisasi terjadi hampir di semua bidang kehidupan. Kemajuan teknologi yang ditandai dengan munculnya internet dapat dioperasikan dengan menggunakan media elektronik seperti komputer. Komputer merupakan salah satu penyebab munculnya perubahan sosial pada masyarakat, yaitu mengubah perilakunya dalam berinteraksi dengan manusia lainnya, yang terus menjalar kebagian lain dari sisi kehidupan manusia, sehingga muncul adanya norma baru, nilai-nilai baru, dan sebagainya. Melalui internet pertukaran informasi dapat dilakukan secara cepat, tepat, serta dengan biaya yang murah. Oleh karena itu, internet dapat menjadi media yang memudahkan seseorang untuk melakukan berbagai jenis tindak pidana yang berbasiskan teknologi informasi (cybercrime) seperti, tindak pidana pencemaran nama baik. Sebelum kemajuan teknologi yang 
menyebabkan adanya tindak pidana pencemaran nama baik melalu media sosial, tindakan pencemaran nama baik dikenal dengan tindakan penghinaan dan fitnah kepada korbannya.

Di masa modern ini, pencemaran nama baik marak terjadi di media sosial. Seperti yang telah terjadi beberapa waktu lalu, Dr. Ira mengirimkan email dama suatu mailing list, yang menjelek-jelekkan rekan kerjanya yakni Dr. Bambang.

Berdasar uraian di atas, menarik untuk ditelaah lebih lanjut mengenai kualifikasi seseorang bisa dikatakan telah melakukan tindak pidana pencemaran nama baik. Dari segi keberlakuan aturan hukum atas tindak pidana tersebut, serta pertanggungjawaban yang melakukan tindak pidana tersebut

\section{Metode Penelitian}

Tipe penelitian yang digunakan dalam penelitian ini adalah penelitian hukum normatif, yaitu suatu jenis penelitian hukum yang diperoleh dari studi kepustakaan, dengan menganalisis suatu permasalahan hukum melalui peraturan perundangundangan, literatur-literatur dan bahanbahan referensi lainnya yang berhubungan dengan Tindak Pidana Pencemaran Nama Baik.

Adapun pendekatan yang digunakan dalam penelitian ini adalah pendekatan perundang-undangan (statute aproach), pendekatan konsep (conseptual approach) dan pendekatan kasus (case approach).

Pendekatan perundang-undangan adalah pendekatan yang dilakukan dengan cara menjawab rumusan masalah yang diajukan berdasarkan ketentuan-ketentuan dalam peraturan perundang-undangan yang ada, baik yang berupa legislasi maupun regulasi yang bersangkut paut dengan tindak pidana pencemaran nama baik.

Pendekatan konsep dilakukan dengan memahami konsep-konsep hukum yang ditemukan oleh sarjana hukum melalui pendapat serta doktrindoktrin. Dalam penelitian ini dikaji berbagai konsep khususnya terkait pencemaran nama baik.

Pendekatan kasus (case approach) yaitu pendekatan dengan melakukan 
analisis putusan pengadilan terkait dengan pencemaran nama baik, yakni kasus Putusan Pengadilan Tinggi Banten Nomor: 151/ PID/ 2012/ PT.BTN seperti yang sudah sedikit dipaparkan dalam latar belakang, untuk mengetahui secara konkrit contoh nyata dari suatu perbuatan dikategorikan pencemaran nama baik ataukah tidak.

\section{Hasil dan Pembahasan}

Pencemaran Nama Baik Melalui Media Sosial Menurut Ketentuan Perundang-Undangan

\section{a) Pencemaran Nama Baik Menurut KUHP}

Bagi masyarakat Indonesia, "kehormatan nama baik" telah tercakup perlindungan dan penjaminannya di dalam Pancasila, baik pada Ketuhanan Yang Maha Esa maupun pada "kemanusiaan yang adil dan beradab", hidup saling menghormati (Leden Marpaung, 2010:7).

Pencemaran nama baik dianggap melanggar norma kesopanan. Pencemaran nama baik sangat erat kaitannya dengan suatu kata penghinaan dimana penghinaan itu sendiri memiliki pengertian perbuatan menyerang nama baik dan kehormatan seseorang.

Dalam KUHP, tindak pidana pencemaran nama baik dijabarkan pada Bab XVI Buku II KUHP adalah dengan mendasarkan delik-delik di dalam KUHP, dalam kaitannya dengan media cetak sebagai pelaku tindak pidana. Pencemaran nama baik seseorang dalam KUHP dirumuskan dalam pencemaran nama baik penistaan secara lisan (Pasal 310 (1) KUHP), menista dengan surat (Pasal 310 (2) KUHP), memfitnah (Pasal 311 KUHP), penghinaan ringan (Pasal 315 KUHP), penghinaan yang bersifat memfitnah (Pasal 317 KUHP), perbuatan menuduh yang bersifat fitnah (Pasal 318 KUHP), penghinaan terhadap orang yang telah meninggal dunia (Pasal 320-321 KUHP).
b) Pencemaran Nama Baik Menurut Undang-Undang No. 40 Tahun 1999 tentang Pers 
Pencemaran nama baik dalam Undang-Undang No. 40 Tahun 1999 tentang Pers, pengaturannya tidak dijelaskan secara spesifik seperti yang ada dalam KUHP. Undang-Undang No. 40 Tahun 1999 menjelaskan bahwa Pers mempunyai fungsi sebagai media informasi, pendidikan, hiburan dan kontrol sosial dan juga dapat berfungsi sebagai lembaga ekonomi seperti yang dijelaskan dalam Pasal 3 Undang-undang No. 40 Tahun 1999. Namun, secara implisit tindak pidana yang diklasifikasikan sebagai pencemaran nama baik dalam UndangUndang No. 40 Tahun 1999 tentang Pers terdapat pada Pasal 5 ayat (1) dan Pasal 13 huruf (a). Selain itu, di dalam Undang-Undang No. 40 Tahun 1999 Tentang Pers, tidak terdapat sanksi pidana penjara terhadap pelaku yaitu wartawan dan media massa (cetak dan elektronik), namun yang ada hanyalah sanksi denda seperti yang dijelaskan Pasal 18 Undang-Undang No. 40 Tahun 1999.

\section{c) Pencemaran Nama Baik Menurut Undang-undang No.}

\section{Tahun 2002 tentang Penyiaran}

Salah satu bentuk pers adalah media elektronik (siaran televisi atau siaran radio). Berdasarkan Undangundang Penyiaran Nomor 32 Tahun 2002 tentang Penyiaran, menegaskan bahwa penyiaran dalam bentuk siaran televisi atau siaran radio, merupakan kegiatan yang mempunyai fungsi sebagai media informasi, pendidikan, hiburan, dan kontrol sosial. Dalam penyelenggaraan fungsi penyiaran tersebut diperlukan aturan hukum untuk menanggulangi berbagai pelanggaran, salah satunya dengan penerapan sanksi pidana di dalam Undang-undang Penyiaran.

Pasal 36 ayat (5) Undang-undang No. 32 Tahun 2002 yang berisi tentang larangan dalam isi siaran yaitu dalam huruf a, isi siaran dilarang bersifat fitnah, menghasut, menyesatkan dan/atau bohong.

Pencemaran Nama Baik
Menurut Undang No. 11 Tahun
2008 jo. Undang-Undang No.19
Tahun 2016 tentang Informasi 


\section{dan Transaksi Elektronik (UU ITE)}

Di dalam Pasal 27 ayat (3) UU ITE seseorang yang dapat dikatakan melanggar ketika memenuhi 4 unsur yaitu (1) unsur setiap orang; (2) Unsur dengan sengaja dan tanpa hak; (3) unsur memiliki muatan penghinaan dan/atau pencemaran nama baik; (4) mendistribusikan dan/atau mentransmisikan dan/atau membuat dapat diaksesnya

Unsur "setiap orang", menurut Pasal 1 angka 21 UU ITE dinyatakan bahwa orang adalah orang perorangan, baik warga negara Indonesia, baik warga negara asing, maupun badan hukum. Jadi unsur setiap orang menurut Pasal 27 ayat (3) adalah "setiap orang perorangan, setiap warga negara, baik warga negara Indonesia maupun warga negara asing maupun suatu badan hukum yang dengan sengaja dan tanpa hak mendistribusikan dan/atau mentransmisikan membuat dapat diaksesnya Informasi Elektronik dan/atau Dokumen Elektronik yang memiliki muatan penghinaan dan/atau pencemaran nama baik.

Unsur "dengan sengaja" dan “tanpa hak"Pasal 27 ayat (3) UU ITE merupakan satu kesatuan bentuk kumulatif yang dalam tataran penerapan hukum harus dapat dibuktikan oleh penegak hukum dalam memberlakukan Pasal tersebut (Nurhadini Kristini, 2009 : 63). Unsur "dengan sengaja" dan "tanpa hak" dimaksudkan bahwa seseorang yang melakukan perbuatan tersebut mengetahui dan menghendaki secara sadar bahwa tindakannya itu dilakukan tanpa hak. Dengan kata lain, pelaku secara sadar mengehendaki dan mengetahui bahwa perbuatan "mendistribusikan" dan/atau "mentransmisikan" dan/atau membuat dapat diaksesnya media informasi elektronik dan/atau dokumen elektronik yang memiliki muatan penghinaan dan/atau pencemaran nama baik. Adapun unsur "tanpa hak" merupakan unsur melawan hukum. Pencantuman unsur tanpa hak dimaksudkan untuk mencegah orang melakukan perbuatan mendistribusikan 
dan/atau mentransmisikan dan/atau

membuat dapat diaksesnya informasi elektronik dan/atau dokumen elektronik yang memiliki muatan penghinaan dan/atau pencemaran nama baik yang bukan haknya untuk menyebarkan informasi tersebut. Unsur "dengan sengaja" dan "tanpa hak" inilah harus dapat dibuktikan secara kumulatif untuk menentukan dapat tidaknya seseorang dipidana berdasarkan Pasal 27 ayat (3) UU ITE.

Unsur "memiliki muatan penghinaan dan/atau pencemaran nama baik" menunjuk pada ketentuan Bab 16 Buku II KUHP tentang penghinaan, khususnya berkaitan dengan ketentuan Pasal 310 dan 311 KUHP (Nurhadini Kristini, 2009 : 64). Kedua Pasal tersebut memberikan dasar pemahaman atau esensi mengenai penghinaan atau pencemaran nama baik yaitu tindakan menyerang kehormatan atau nama baik orang lain dengan maksud diketahui oleh umum. Kehormatan dan nama baik memiliki pengertian yang berbeda, tetapi keduanya tidak dapat dipisahkan satu dengan yang lainnya, karena menyerang kehormatan seseorang akan berakibat terhadap kehormatan serta nama baiknya tercemar, demikian juga sebaliknya, menyerang nama baik seseorang sama saja akan berakibat tercemarnya nama baik dan kehormatan seseorang pula. Oleh sebab itu, menyerang salah satu diantara kehormatan atau nama baik sudah cukup dijadikan alasan untuk menuduh seseorang melakukan penghinaan (Mudzakir, 2004 :18).

Unsur "mendistribusikan dan/atau mentransmisikan dan/atau membuat dapat diaksesnya" di dalam penjelasan mengenai Unsur mendistribusikan UU ITE tidak menjelaskan definisi dari mendistribusikan oleh karena itu harus diambil definisi baku melalui Kamus Besar Bahasa Indonesia yang memberikan definisi sebagai berikut menyalurkan (membagikan, mengirimkan) kepada beberapa orang atau ke beberapa tempat (seperti pasar, toko). Unsur mentransmisikan, UU ITE juga tidak menjelaskan definisi dari mentransmisikan. Oleh karena itu, harus diambil definisi baku melalui 
Kamus Besar Bahasa Indonesia yang memberikan definisi yaitu mengirimkan atau meneruskan pesan dari seseorang (benda) kepada orang lain (benda lain).Unsur membuat dapat diaksesnya, UU ITE juga sama sekali tidak memaparkan definisi dari membuat dapat diaksesnya selain hanya memberikan definisi tentang akses yaitu kegiatan melakukan interaksi dengan Sistem Elektronik yang berdiri sendiri atau dalam jaringan.

Pertanggungjawaban Pidana Pelaku Pencemaran Nama Baik Menurut Ketentuan Perundang-Undangan

\section{a) Pertanggungjawaban Pidana Pelaku Pencemaran Nama Baik Menurut Kitab Undang Undang Hukum Pidana (KUHP)}

Dalam hukum pidana konsep liability atau "pertanggung jawaban" itu merupakan konsep sentral yang dikenal dengan ajaran kesalahan. Dalam bahasa Latin ajaran kesalahan ini disebut juga dengan mens rea. Suatu perbuatan tidak mengakibatkan seorang bersalah kecuali jika pikirn orang itu jahat. Doktrin mens rea itu dilandaskan pada maxsim actuis nonfacit reum nisi mens sit rea, yang berarti "suatu perbuatan tidak mengakibatkan seseorang bersalah jika pikiran orang tersebut jahat" (Roeslan Saleh 1982 : 23).

Kitab Undang - undang Hukum Pidana tidak menyebutkan secara eksplisit sistem pertanggungjawaban pidana yang dianut. Beberapa Pasal KUHP sering menyebutkan kesalahan berupa kesengajaan atau kealpaan. Namun sayang, kedua istilah tersebut tidak dijelaskan lebih lanjut oleh Undang-Undang tentang maknanya. Jadi, baik kesengajaan maupun kealpaan tidak ada keterangan lebih lanjut dalam KUHP. Kedua kata itu sering dipakai dalam rumusan delik, seakan-akan sudah pasti, tetapi tidak tahu apa maknanya. Hal itu seakanakan tidak menimbulkan keraguraguan lagi dalam pelaksanaannya (Roeslan Saleh, 1982 : 98).

Kesalahan, pertanggungjawaban, dan pidana adalah ungkapan-ungkapan yang terdengar dan digunakan dalam percakapan sehari-hari, dalam moral, agam dan hukum. Tiga unsur itu 
berkaitan suatu dengan yang lain, dan berakar dalam suatu keadaan yang sama yaitu adanya pelanggaran terhadap sistem aturan-aturan. Sistem aturan-aturan ini dapat bersifat luas dan beraneka macam (hukum perdata, hukum pidana, aturan moral dan sebagainya). Kesamaan dari ketiganya bahwa mereka meliputi suatu rangkaian aturan tentang tingkah laku yang diikuti oleh suatu kelompok tertentu. Jadi sistem yang melahirkan konsep kesalahan, pertanggungjawaban dan pemidanaan itu adalah sistem normatif.

Berpangkal tolak kepada sistem normatif yang melahirkan konsep kesalahan, pertanggungjawaban dan pemidanaan itu, dicoba menganalisis tentang pertanggungjawaban pidana. Bertanggung jawab atas sesuatu perbuatan pidana berarti yang bersangkutan secara sah dapat dikenakan pidana atas perbuatan tersebut (Roeslan Saleh, 1982 : 33-34). Untuk meminta pertanggungjawaban pidana seseorang, pertama-tama harus seseorang tersebut harus melakukan perbuatan pidana sebagaimana diatur dalam Pasal 1 KUHP berbunyi:

(1) Suatu perbuatan tidak dapat dipidana, kecuali berdasarkan kekuatan ketentuan perundangundangan pidana yang telah ada

(2) Bilamana ada perubahan dalam perundang-undangan sesudah perbuatan dilakukan, maka terhadap terdakwa diterapkan ketentuan yang paling menguntungkannya.

Walaupun tidak secara tegas disebut dalam KUHP tentang adanya asas tiada pidana tanpa kesalahan, namun asas tersebut diakui melalui Pasal 1 ayat (1) KUHP di atas (Erdianto Effendi, 2011:108).

Suatu perbuatan dikatakan melawan hukum apabila orang tersebut melanggar undang-undang yang ditetapkan oleh hukum. Tidak semua tindak pidana merupakan perbuatan melawan hukum, karena ada alasan pembenar berdasarkan Pasal 50, Pasal 51 KUHP. Sifat melawan hukum itu sendiri meliputi :

a) Sifat formil yaitu bahwa perbuatan tersebut diatur oleh undangundang. 
b) Sifat materiil yaitu bahwa perbuatan tersebut tidak selalu harus diatur dalam undangundang, tetapi juga dengan perasaan keadilan dalam masyarakat.

Berdasarkan pandanganpandangan tersebut, dapat dirumuskan pengertian pertanggungjawaban pidana yaitu sebagai penilaian keadaaan dan kemampuan seseorang yang diduga melakukan tindak pidana, apakah ia dapat dimintai pertanggungjawaban atau tidak. Sedangkan untuk menilai bagaimana keadaan tentang terjadinya suatu tindak pidana, haruslah diketahui adanya kesalahan dari si pelaku, untuk menilai kemampuan si pelaku haruslah dilakukan pengujian kesehatan jiwa si pelaku apakah ia tergolong mampu atau tidak untuk bertanggung jawab (Roeslan Saleh, 1982:109).

Jika diperhatikan dengan seksama, di dalam KUHP Buku II terdapat perbedaan antara kesengajaan dan kealpaan. Rumusan-rumusan dalam KUHP membedakan antara kedua hal tersebut: a. dengan sengaja; b. karena kealpaan. Tidak dijelaskan lebih lanjut seperti apa kesengajaan dan kealpaan tersebut. Namun, dari doktrin-doktrin yang ada, dapat disimpulkan bahwa untuk pertanggungjawaban pidana perlu dibuktikan terlebih dahulu unsur kesalahan.

Untuk mengetahui pertanggungjawaban pidana pada tindak pidana pencemaran nama baik, perlu dilihat dari Pasalnya terlebih dahulu, terkait kesalahan apa yang ditekankan. Berdasarkan ketentuan dalam KUHP, pasal-pasal yang digunakan untuk menjerat tindak pidana pencemaran nama baik diatur dalam Bab XVI tentang penghinaan yang termuat dalam Pasal 310 sampai dengan Pasal 321 KUHP. Pasal 310 dapat digunakan untuk menjerat pelaku pencemaran nama baik yang mempunyai unsur subjektif dengan sengaja, sedangkan unsur objektifnya menyerang kehormatan atau nama baik seseorang dengan menuduhkan sesuatu hal, yang maksudnya agar supaya hal itu diketahui oleh umum (Alexander Imanuel Korassa Sonbai I Ketut Keneng, 2016:3). Di dalam Kitab 
Undang-Undang Hukum Pidana dititikberatkan kepada perbuatan itu yaitu pada unsur kesengajaan yang dilakukan oleh pelaku, sehingga untuk melakukan pembuktian bersalahnya pelaku, maka dititikberatkan pada kesengajaan atas perbuatannya tersebut.

Tindak pidana kehormatan termasuk delik aduan diatur dalam Bab VIII, Pasal 72, Pasal 73, Pasal 74, dan Pasal 75 KUHP. Suatu pengaduan adalah suatu pernyataan tertulis dari orang yang berhak untuk mengadu bahwa ia menghendaki penuntutan pelaku suatu pelanggaran tindak pidana. Konsep "orang yang mengadu" jika yang menderita atau korban kejahatan suatu tindak pidana sudah dewasa, maka tidak menimbulkan masalah karena korban itulah yang berhak mengadu, apabila korban yang ingin melakukan aduan adalah anak yang belum dewasa, hal ini diatur dalam Pasal 72 dan 73 KUHP.

Berdasarkan rumusan Pasal 72 KUHP, maka yang berhak mengadu adalah Wakilnya yang sah, Wali pengawas/ wali pengampu, Keluarga sedarah sampai derajat ketiga. Jika korban kejahatan telah meninggal dunia, maka pengaduan diatur oleh Pasal 73 Kitab Undang-Undang Hukum Pidana yakni Orang tuanya, Anaknya, Istri/Suami yang masih hidup (Leden Marpaung,2020:77-78).

\section{b) Pertanggungjawaban Pidana Pelaku Pencemaran Nama Baik di dalam Undang-Undang No. 40 Tahun 1999 tentang Pers}

Pertanggungjawaban pers setelah berlakunya Undang-Undang No. 40 Tahun 1999 tentang Pers, secara eksplisit diatur dalam Pasal 12 dan Pasal 18 ayat (2), bunyi pasalnya yaitu:

\section{Pasal 12}

"Perusahaan pers wajib mengumumkan nama, alamat, dan penanggung jawab secara terbuka melalui media yang bersangkutan; khusus untuk penerbitan pers ditambah nama dan alamat percetakan."

Berdasarkan penjelasan Pasal 12 Undang-Undang Nomor 40 Tahun 1999 tentang Pers, menyatakan yang 
dimaksud penanggung jawab adalah penanggung jawab perusahaan pers yang meliputi bidang usaha dan bidang redaksi, sepanjang menyangkut pertanggung jawaban pidana menganut ketentuan perundang-undangan yang berlaku.

Pasal 18 ayat (2)

Perusahaan pers yang melanggar ketentuan Pasal 5 ayat (1) dan ayat (2), serta Pasal 13 dipidana, dengan pidana denda paling banyak Rp 500.000.000,00 (lima ratus juta rupiah)

Kemudian berdasarkan penjelasan Pasal 18 ayat (2) UndangUndang Nomor 40 Tahun 1999 tentang Pers, menyatakan dalam hal pelanggaran pidana dapat dikenakan ketentuan pidana denda.

Berdasarkan Pasal 12 dan Pasal 18 ayat (2) dapat disimpulkan bahwa pertanggung jawaban pers, yaitu: (Idriyanto Seno Adji, 2005:27-28)

1) Berdasarkan Undang-Undang No. 40 Tahun 1999 tentang Pers, pertanggungjawaban pers meliputi pertanggungjawaban fiktif, karena masih menempatkan penanggung jawab perusahaan pers yang meliputi bidang usaha dan bidang redaksi. Pihak inilah yang dapat bertanggungjawab terhadap pemberitaan apabila terdapat pelanggaran hukum adalah pemimpin redaksi;

2) Berdasarkan penjelasan Pasal 12 Undang-Undang No. 40 Tahun 1999 tentang Pers, menyangkut pertanggungjawaban pidana menganut ketentuan perundangundangan yang berlaku. Makna yang berlaku tersebut dimaksudkan sebagai "individual responsibility" yang menyangkut actual and factual wrongdoer (pelaku utama).

\section{c) Pertanggung Jawaban Tindak Pidana Pencemaran Nama Baik di dalam Undang-Undang No. 32 Tahun 2002 tentang Penyiaran}

Pasal 57 huruf d, mengatur sanksi pidana terhadap pelanggaran terhadap Pasal 36 ayat (5) yang berisi tentang larangan dalam isi siaran yaitu dalam huruf a, isi siaran dilarang bersifat fitnah, menghasut, menyesatkan 
dan/atau bohong. Hal ini mengartikan bahwa apabila terjadi pelanggaran, yaitu terhadap isi siaran, salah satunya melalui siaran televisi, terdapat fitnah yang kemudian mencemarkan nama baik, seseorang yang bertanggung jawab dalam lembaga penyiaran tersebut (stasiun televisi) dapat dijatuhi pidana.

Pertanggungjawaban yang diatur dalam Undang-Undang Nomor 32 Tahun 2002 tentang Penyiaran, didasarkan pada pasal Pasal 54, yaitu:

Pasal 54

Pimpinan badan hukum lembaga penyiaran bertanggung jawab secara umum atas penyelenggaraan penyiaran dan wajib menunjuk penanggung jawab atas tiap-tiap program yang dilaksanakan.

Dapat diartikan bahwa pemimpin badan hukum dalam lembaga penyiaran bertanggung jawab secara umum, namun pertanggungjawaban utama ditunjuk terhadap penanggung jawab setiap program. Apabila terjadi pelanggaran hukum dalam suatu tayangan atau siaran, maka yang bertanggung jawab adalah penanggung jawab siaran yaitu produser siaran.

\section{d) Pertanggungjawaban Pidana Pelaku Pencemaran Nama Baik menurut Undang-Undang No. 11 Tahun 2008 jo. Undang- Undang No.19 Tahun 2016 tentang Informasi dan Transaksi Elektronik ( UU ITE)}

UU ITE merupakan Lex Specialis dari Kitab Undang-Undang Hukum Pidana karena merupakan pengkhususan dari penghinaan dalam Kitab Undang-Undang Hukum Pidana di ranah internet. Diketahui bahwa UU ITE Pasal 27 ayat (3) mengatur tentang pencemaran nama baik dalam media sosial. Di dalam Pasal tersebut terdapat dua unsur, yakni unsur subjektif serta unsur objektif. Unsur subjektif dari Pasal tersebut adalah unsur kesalahan yang dimaksud dengan adanya kata-kata dengan sengaja sedangkan unsur objektif pasal tersebut adalah adanya perbuatan mendistribusikan dan/atau mentransmisikan dan/atau membuat dapat diaksesnya Informasi elektronik 
dan/atau Dokumen Elektronik yang memiliki muatan penghinaan dan/atau pencemaran nama baik (Alexander Imanuel Korassa Sonbai I Ketut Keneng, 2016:4).

Di dalam UU ITE ini untuk pertanggungjawaban pidana pelaku ditekankan pada unsur subjektifnya, yakni kesalahan dengan maksud kesengajaan yang dilakukan oleh pelaku yang melakukan tindakan seperti yang terdapat di Pasal 27 sampai dengan Pasal 36 UU ITE. Untuk membuktikan bahwa seorang pelaku melakukan pencemaran nama baik di media sosial, penegak hukum harus dapat membuktikan bahwa pelaku secara sadar menghendaki dan mengetahui perbuatannya.

Untuk itu, yang harus dibuktikan agar seseorang dapat dikenakan pencemaraan nama baik dengan UU ITE adalah adanya kesengajaan dari sang pelaku dalam tindakannya "mendistribusikan" dan/atau "mentransmisikan" dan/atau "membuat dapat diaksesnya informasi elektronik dan/atau informasi elektronik" adalah memiliki muatan penghinaan/pencemaran nama baik.

Di dalam contoh kasus-kasus pencemaran nama baik yang telah dijabarkan sebelumnya maka untuk dapat dijerat dengan Pasal Pencemaran Nama Baik di dalam UU ITE haruslah dilihat terlebih dahulu apakah pelaku tersebut bisa bertanggung jawab secara akal. Jika pelaku bisa bertanggung jawab secara akal, maka untuk dibuktikan bersalah maka haruslah pelaku dapat dibuktikan memenuhi unsur kesalahan, yakni kesengajaan, bahwa orang itu secara sadar dan sengaja mengetahui apa yang dilakukannya memuat pencemaran nama baik.

Seperti Kasus Prita Mulyasari ditahan karena email keluhkan layanan rumah sakit ia sebarkan melalui mailing list, Kasus Farah dihukum karena mencaci di Facebook, Kasus yang terjadi pada Farhat Abbas yang menuliskan kicauan yang menyinggung perasaan dari Achmad Dhani melalu media sosial, Kasus Benhan yang dihukum karena cemarkan nama Misbakhun di Twtiter, serta kasus penulisan status BBM 
menyerang oleh Nurdin Halid yang membuat ia dilaporkan polisi. Dari beberapa contoh kasus pencemaran nama baik di media sosial ini untuk dapat dijerat dengan Pasal Pencemaran Nama Baik dalam UU ITE ialah ditekankan pada adanya kesalahan pelaku, yakni terdapat unsur sengaja oleh sang pelaku atas tindakannya, "mendistribusikan" dan/atau "mentransmisikan" dan/atau “membuat dapat diaksesnya informasi elektronik dan/atau informasi elektronik" ditujukan kepada seseorang atau pihak tertentu serta memuat unsur penghinaan/ pencemaran nama baik.

Dengan melihat contoh kasus yang ada tersebut, maka baik di dalam Kitab Undang-Undang Hukum Pidana, Pasal 310 dan 311, maupun di dalam UU ITE Pasal 27, kedua-keduanya untuk pertanggungjawaban pidananya sama-sama melihat dari unsur kesalahan sang pelaku, yang mana kesalahan tersebut berupa kesengajaan. Kesengajaan sang pelaku itulah yang harus dibuktikan oleh penegak hukum. Hal ini terlihat dari adanya kata-kata "dengan sengaja" dalam Pasal-Pasal tersebut.

e) Analisis Contoh Kasus mengenai Pertanggungjawaban Pidana Dalam Kasus Tindak Pidana Pencemaran Nama Baik di Media Sosial Menurut UU ITE Dengan Putusan Pengadilan Tinggi Banten Nomor: 151/ PID/ 2012/ PT.BTN

Dr. Ira menulis email yang berisi penuduhan Dr.Bambang sebagai pelaku pelecehan seksual, padahal faktanya tidak seperti itu. Putusan Pengadilan Tinggi Tangerang atas Banding yang diajukan menyatakan bahwa Dr. Ira bersalah dan dijerat dengan Pasal 27 UU ITE. Bahwa Dr. Ira terbukti secara sah dan meyakinkan bersalah melakukan tindak pidana : "Dengan sengaja dan tanpa hak Mendistribusikan dan mentransmisikan dan membuat dapat diaksesnya Informasi elektronik yang memiliki muatan penghinaan dan/atau pencemaran nama baik".

Pertanggungjawaban pidana yang akan dibahas disini terkait dengan pencemaran nama baik, ialah terhadap 
tindakan Dr. Ira dalam mengirim email ke banyak orang terkait Dr. Bambang melakukan pelecehan seksual (yang ternyata hanyalah fakta diputar balikkan) membuatnya dikenai Pasal 27 ayat (3) UU ITE oleh Pengadilan Tinggi Banten.

Pasal 27 ayat (3) UU ITE berbunyi:

(3) Setiap orang dengan sengaja dan tanpa hak mendistribusikan dan/atau mentransmisikan dan/atau membuat dapat diaksesnya Informasi Elektronik dan/atau Dokumen Elektronik yang memiliki muatan penghinaan dan/atau pencemaran nama baik

Unsur pertama dari Pasal tersebut: setiap orang. Dalam unsur setiap orang, biasa terkait dengan barangsiapa, yakni siapa yang melakukan. Dalam hal ini, terkait subjek hukum yang melakukan tindak pidana, dalam hal ini yang didakwa ialah Dr. Ira.

Unsur kedua ialah unsur dengan sengaja dan tanpa hak. Dalam kasus tersebut, Dr. Ira dengan sengaja mengirimkan email ke orang-orang tersebut. Disini, unsur kesengajaan terlihat dari email yang dikirimnya ditujukan agar dibaca oleh pihak-pihak yang dituju.

Unsur ketiga ialah mendistribusikan dan/atau mentransmisikan dan/atau membuat dapat diaksesnya. Dr. Ira telah dan/atau mentransmisikan dan/atau membuat dapat diaksesnya email yang dikirim sendiri olehnya secara sengaja.

Unsur keempat dan yang terakhir ialah muatan penghinaan dan/atau pencemaran nama baik. Muatan pencemaran nama baik disini jelasjelas ialah yang dilakukan oleh Dr. Ira, menuduh Dr. Bambang atas perbuatan pelecehan seksual yang tidak dilakukan olehnya.

Dengan terpenuhinya ke empat unsur dalam Pasal 27 ayat (3) UU ITE maka Dr. Ira telah melakukan perbuatan pencemaran nama baik atas Dr. Bambang. Terbuktinya kesengajaan dari Dr. Ira, membuatnya dikenai tanggungjawab pidana atas 
tindakannya tersebut.

\section{f) Analisis Kasus Tindak Pidana Pencemaran Nama Baik di Media Sosial Menurut UU ITE Dengan Putusan Pengadilan Tinggi Masohi No. 45 /Pid.B/2012/PN.MSH}

Terdakwa Leco Maba alias Leco alias Econ, pada hari Jumat tanggal22 Oktober 2010 sekitar pukul 13.15 WIT saat itu ia baru tiba di rumah setelah shalat Jumat pada mesjid Kampung Hatui, ia saat masih berada di atas sepeda motor, melihat bahwa Kadir Rumuar, mencungkil kotak amal di depan Masjid Attaqwa, tepatnya di pintu masuk halaman Masjid Attaqwa Kampung Jawa. Leco melihat setelah mencungkil, Kadir membawa kotak amal tersebut menggunakan motor milk Haji Amrin Mantuinai.

Melihat kejadian itu, Leco Maba mengakses Facebook melalui Hpnya, kemudian ia menuliskan dan mengupdate status di akun facebooknya "Telah hilang 1 (satu) buah kotak amal milik Panitia Pembangunan Mesjid Attaqwa Kampung Jawa yang berada di lokasi pembangunan mesjid, dan menurut saksi mata yang mencuri adalah saksi korban Kadir Rumuar".

Padahal, dalam kejadian sebenarnya, Korban Kadir selaku muazin masjid diberikan kuasa untuk memindahkan kotak amal tersebut sendirian dikarenakan kondisi masjid yang sedang adanya renovasi. Korban Kadir merasa Leco sengaja menulis hal tersebut karena masalah yang dahulu ada diantara mereka berdua. Korban Kadir kemudian menuntut kepada pengadilan, agar Leco dikenai "Pencemaran nama baik/penghinaan" sebagaimana diatur dalam Pasal 27ayat (3) Jo Pasal 45 ayat (1) UU ITE. Pengadilan Negeri Masohi kemudian memvonis Leco dengan tuntutan tersebut.

Pertanggungjawaban pidana yang akan dibahas disini terkait dengan tuntutan pencemaran nama baik terhadap terdakwa Leco. Tindakan Leco dalam mengupdate status berisi fitnah terhadap Kadir yang mengambil kotak amal membuatnya dikenai Pasal 27 ayat (3) UU ITE oleh Pengadilan 
Negeri Masohi. Adapun Pasal 27 ayat

(3) UU ITE berbunyi:

(3) Setiap orang dengan sengaja dan tanpa hak mendistribusikan dan/atau mentransmisikan dan/atau membuat dapat diaksesnya Informasi Elektronik dan/atau Dokumen Elektronik yang memiliki muatan penghinaan dan/atau pencemaran nama baik

Unsur pertama dari Pasal tersebut: setiap orang. Dalam unsur setiap orang, biasa terkait dengan barangsiapa, yakni siapa yang melakukan. Dalam hal ini, terkait subjek hukum yang melakukan tindak pidana, dalam hal ini yang didakwa ialah Econ.

Unsur kedua ialah unsur dengan sengaja dan tanpa hak. Dalam kasus tersebut, Leco dengan sengaja mengirimkan status yang memfitnah Kadir, terlebih ia memiliki histori adanya masalah dengan Kadir. Disini, unsur kesengajaan terlihat dari ia sengaja mengupdate status di
Facebook agar bisa dilihat banyak orang, dan ia tidak memiliki hak untuk menyebarkan informasi (tuduhan) tersebut.

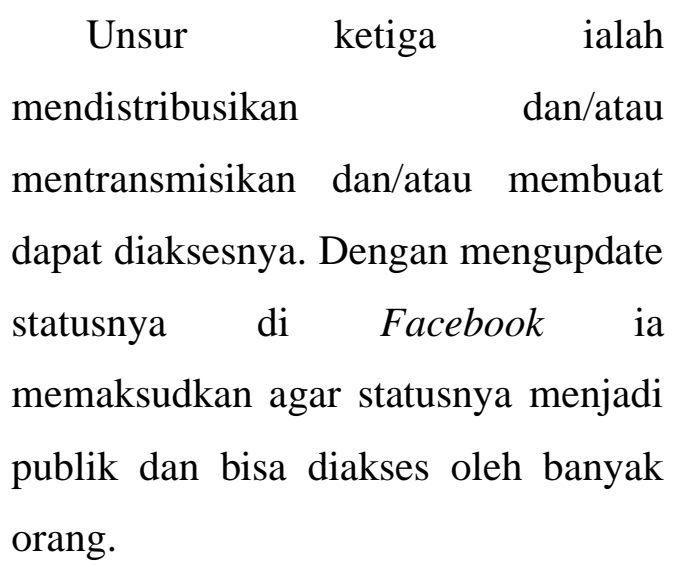

Unsur keempat dan yang terakhir ialah muatan penghinaan dan/atau pencemaran nama baik. Muatan pencemaran nama baik disini ialah ia menuduh bahwa Kadir lah yang telah mengambil kotak amal masjid.

Dengan terpenuhinya ke empat unsur dalam Pasal 27 ayat (3) UU ITE maka Leco telah melakukan perbuatan pencemaran nama baik atas Kadir. Terbuktinya kesengajaan dari Leco membuatnya dikenai tanggungjawab pidana atas tindakannya tersebut.

\section{Simpulan}

Pasal ini bukan berarti melarang hak setiap orang untuk bebas 
berpendapat seperti yang dijelaskan di Undang-Undang Dasar Republik Indonesia Pasal 28 dan juga dalam Undang-Undang Republik Indonesia No. 9 Tahun 1998 tentang Kemerdekaan Penyampaian Pendapat di muka Umum. Pasal 1 dan 2 bukan tidak menjamin hak setiap individu atas kehormatannya atau reputasinya, akan tetapi terdapat batasan-batasan yang sudah diatur di dalam KUHP. Pasal 27 UU ITE mempunyai unsurunsur yang hampir sama dan UU ITE ini merupakan lex specialis dari Tindak Pidana Pencemaran Nama Baik yang telah lebih dulu diatur dalam KUHP secara lebih luas. Pasal tersebut, bukan melarang, hanya ia memiliki tujuan agar setiap orang yang ingin mengunggah informasi, gambar di media sosial, mendistibusikan maupun mentransmisikan, ia harus memikirkan terlebih dahulu apakah hal yang akan di upload di media sosial tersebut dapat menimbulkan terpenuhinya unsur-unsur tindak pidana pencemaran nama baik yang dalam UU ITE meliputi 4 unsur : (1) unsur setiap orang; (2) Unsur dengan sengaja dan tanpa hak; (3) unsur memiliki muatan penghinaan dan/atau pencemaran nama baik; mendistribusikan dan/atau mentransmisikan dan/atau membuat dapat diaksesnya.

Untuk dapat dikenakan pertanggung jawaban pidana dalam tindak pidana pencemaran nama baik di media sosial, seseorang harus memenuhi unsur-unsur pertanggungjawaban pidana pada umumnya, yakni sebagai subjek hukum yang mampu bertanggung jawab. Kemudian, untuk dapat dipertanggungjawabkan secara pidana, harus dibuktikan oleh jaksa adanya unsur kesengajaan dari si pelaku dalam perbuatannya tersebut.

\section{Saran}

Adanya revisi UU ITE yang ada dengan mengurangi masa tahanan, membuat tindak pidana pencemaran nama baik menjadi tindak pidana ringan, justru merupakan suatu kemunduran. Diharapkan adanya perubahan terhadap masa hukuman bisa ditangguhkan, agar masyarakat 
khalayak ramai dapat berhati-hati dalam mengunggah konten di media sosial. Pengetatan sanksi perlu demi mengurangi tindak pidana pencemaran nama baik di media sosial.

\section{Daftar Pustaka}

\section{Buku}

Effendi. Erdianto, 2011, Hukum Pidana Indonesia, Bandung.

Moeljatno. 2009, Asas - asas Hukum Pidana, Jakarta : PT Rineka Cipta.

Marpaung, Leden, 2010, Tindak Pidana Terhadap Kehormatan, Jakarta: PT Sinar Grafika.

Mudzakir, 2004, Delik Penghinaan dalam Pemberitaan Pers Mengenai Pejabat Publik Dictum 3, Yogyakarta: Atmajaya Pres.

Saleh, Roeslan, 1982, Pikiran-Pikiran Tentang Pertanggungan Jawaban Pidana. Jakarta.

Sudarto, 1990, Hukum Pidana I, Cetakan kedua (Semarang Yayasan Sudarto d/s Fakultas Hukum Universitas Diponegoro).

https://www.merdeka.com/peristiwa/in i-korban-korban-keganasanuu-ite/farah dihukum-karena- mencaci-di-facebook.html, diakses pada tanggal 9 November 2016.

www.Merdeka.com/www.baranews.co , dikunjungi pada tanggal 9 November 2016.

http://www.suduthukum.com/2016/11/ unsur-unsur-pencemarannama-baik-dalam.html , di akses pada tanggal 12 Januari 2017.

\section{Skripsi/Tesis}

Kristini, Nurhadini. "Tindak Pidana Dibidang Informasi dan Transaksi Elektronik yang Bermuatan Peghinaan Dan Pencemaran Nama Baik." Tesis, Fakultas Hukum Airlangga, 2009.

Imanuel Korassa Sonbai I Ketut Keneng, Alexander, PertangungJawaban Pidana PelakuTindak Pidana Pencemaran Nama Baik Melalui Media Sosial dalam Hukum Pidana Indonesia, Fakultas Hukum Udayana,03 April 2016. 